\title{
Juridical Analysis of Legal Protection on Agricultural Land Pawner After the Issuance of Law No. 56 Prp of 1960
}

\author{
Saniah $^{1^{*}} \quad$ Yusriana $^{2} \quad$ Sri Istiawati ${ }^{2} \quad$ Deliani $^{2}$ \\ 1.Lecture Of STIE Nusa Bangsa Medan, Jl. Bhayangkara Nomor 484 Medan 20221, Indonesia \\ 2.Lecture Of Amir Hamzah University Medan, Jl. Willem Iskandar Psr. V Barat, Medan Estate 20221, Indonesia
}

\begin{abstract}
This study aims to determine the legal protection of pawning of agricultural land after the issuance of Law No. 56 Prp of 1960 and also to understand the implementation of the law in the midst of the society. This study is a normative legal research using sources of legal material consisting of primary legal materials, secondary legal materials, and tertiary legal materials. To collect legal materials, study documents are used. The conclusion is that in terms of the juridical aspects of article 7 of Law No. 56 Prp of 1960 has provided legal protection to land pawns or landowners, but when viewed from the implementation side of the regulation based on research carried out by several previous researchers, article 7 of Law No. 56 Prp of 1960 has not been implemented. The society in general still adheres to the mortgage agreement which is subject to the customary law where the mortgage transaction takes place.
\end{abstract}

Keywords: Legal Protection, Land Pawn, Law No. 56 Prp of 1960

DOI: $10.7176 / \mathrm{JEP} / 10-8-05$

Publication date:March $31^{\text {st }} 2019$

\section{INTRODUCTION}

Agricultural land pawnshops are not something strange to Indonesian, their existence has long been known, lived and developed in the midst of the society. It can be said that almost all indigenous peoples know and practice this mortgage transaction. The differences that are not principle only in the execution of the transaction. For example, in Aceh the mandatory deed must include a solemnization of a marriage form, in Batak community the pawn transaction must be carried out on "NasiNgebul", in Minangkabau there is a custom of pawn buyers every year giving rice to the seller or landowner as a sign that the pawn seller has the right to redeem (SuroyoWignyodipuro, 1987: 209).

After the promulgation of the Agrarian Basic Law No. 5 of 1960, then it was abbreviated as UUPA No. 5 of 1960 on September 24, 1960, a pawn of agricultural land which was initially governed by customary law where the transaction took place, its existence is still recognized, only in UUPA No. 5 of 1960 this lien is classified into temporary land rights.

Article 53 UUPA No. 5 of 1960 states "Rights that are temporary in nature as referred to in Article 16 paragraph 1 letter $\mathrm{h}$ are mortgage rights, profit sharing business rights, hitching rights and leasing rights of agricultural land, are regulated to limit the characteristics that are contrary to this law and these rights are attempted to remove it in a short time.

The meaning that can be concluded from article 53 of UUPA No. 5 of 1960 specifically regarding the liens that the existence of liens must be removed, only to be removed in a short time has not been clear yet, regarding the presence of the UUPA has reached 58 years since the promulgation and pawning transactions still take place in midst lives of Indonesian.

Land liens according to customary law are formulated as land surrenders to receive payments in cash under the condition that the landowner has the right to return the land by redeeming it (Imam Sudiyat, 1981: 2). According to customary law, selling pawns or pawning agreements is a stand-alone agreement, so it only consists of one type of agreement. The pawn holder cannot force the landowner to redeem the land. If the pawn holder needs money then he may transfer the money or double the pawn to another party, under the condition that it is not allowed to sell off (LiliekIstiqomah, 1982: 62).

Pawn transactions that are subject to customary law do not recognize the time limit in terms of redemption. If there is no kind of promise, then when it comes to redeeming the mortgaged land, it will be for the party who pawned or owned the land. If he dies, then this lien is transferred to his heirs. So the pawn goes on and on for generations, some even reach 100 years. Those who accept pawns must not force the landowner to sell the land to him (RustandiArdiwilaga in Eddy Ruchyat, 1983: 58).

After UUPA No. 5 of 1960 was promulgated, then the Government published Law No. 56 Prp of 1960 concerning "Determination of Agricultural Land Area". Article 7 of the law, states "Whosoever controls the agricultural land with liens which at the time of entry of this regulation has lasted 7 years or more must return the land to its owner within one month after the existing plants have been harvested with no right to sue ransom payment ". If the pawn period of the land is less than 7 years and if the pawn seller wants to re-redeem the land that has been pawned, then the liability of the pawn seller to pay ransom is calculated using the following formula: 
$(7+1 / 2)$ - the pawn period multiplied by the pawn money divided by 7 .

The government agrees with the above statement, because the pawned land is in the hands of the pawn holder and the pawn holder has enough to feel the benefits of the pawned land, so if the land is returned to the owner, it does not cause harm to the pawn holder.

Decision of the Supreme Court on March 11, 1961 No. 4K / Sip / 1961, according to article 7 of Law No. 56 Prp of 1960, the land which was pawned for more than 7 years must be returned by the pawn holder to the land owner without paying ransom and without giving any loss.

Decision of the Supreme Court on March 6,1971 No. 810 / e / Sip / 1970 decided that according to article 7 of Law No. 56 Prp of 1960 is coercive and cannot be softened simply because it has been agreed between the two parties to the dispute.

Observing the decision of the Supreme Court above can be interpreted that Article 7 of Law No. 56 Prp of 1960 must be carried out as it should.

However, in the real conditions, the implementation of pawn agricultural land in the midst of the community still adheres to the customs of the local society. For example, in Aceh, the Aceh pawn agreement is called "Gala", in the form of an agreement that generally knows that someone owes someone else in the form of money by giving an object in the form of agricultural land or garden which can produce as an object gala (Marsyuddin: Https://media. Research.com/media/publication/13952-10-eksisten- perjanjian-gala-gadai-tanah-pertanian-pada-masyarakataceh-dikecamatan.pdf). In the MeurahMulia sub-district of North Aceh Regency, gala geumala (pawning) cannot be separated from the community anymore, because "gala" or pawn is already so entrenched and very meaningful to the society in MeurahMulia sub-district. The ease and efficiency factor is the main reason for the maintenance of the land pawn by the society in the sub-district of MeurahMulia of North Aceh regency, when there are members of the society who unexpectedly need a relatively large amount of money, only by pawning the land as the only way and almost no other way (Marsyuddin: Htps://media.neliti.com/media/publication/13952-10- eksistensiperjanjian-gala-gadai-tanah-Pertanian-pada-masyarakat-aceh-dikecamatan.pdf).

Judging from the formal juridical aspects, article 7 of Law No. 56 Prp of 1960 has provided legal protection to the pawn provider or landowners, but based on the results of studies conducted by some of the previous researcher encountered irregularities with article 7 of Law No. 56 Prp of 1960 on aspects of its implementation.

Based on the description above, it is interesting for the author to analyze further about legal protection on the agricultural land pawner based on Law No. 56 Prp of 1960.

\section{Problem Formulation.}

The problem formulation in this study are:

a. What is the legal protection provided by law on agricultural land pawner after the issuance of Law No. 56 Prp of 1960 ?

b. How is the implementation of Law No. 56 Prp of $1960 ?$.

\section{Research Objectives.}

The objectives to be achieved from this study are:

a. To find out the legal protection on agricultural land pawning after the issuance of Law No. 56 Prp of 1960.

b. To understand the implementation of Law No. 56 Prp of 1960 in the midst of the society.

\section{Research Methods.}

The research approach used in this study is the statute approach. This approach is carried out by examining the laws and regulations relating to the problems being studied (Peter Mahmud Marzuki, 2007: 93).

Sources of legal material in this study consist of primary legal materials, namely legal material in the form of legislation (Jhoni Ibrahim, 2006: 295), and secondary legal material in the form of legal books including theses, legal dissertations, journals law, legal dictionaries and comments on court decisions relating to research issues (Peter Mahmud Marzuki, 2014: 195-196).

To collect legal materials needed in this study, library research techniques are used. The tool used to collect legal materials is the document structure. Analysis of legal materials in this study was conducted using qualitative methods (SuharsiniArikunto, 1996: 293).

\section{Discussion and Results.}

\section{1. Agricultural Land Pawner in the Perspective of Customary Law.}

Long before the publishing of Law No. 56 Prp of 1960, the agricultural land pawn agreement was not something strange to Indonesian society. This pawnshop has long been practiced among the Indonesian, growing and developing. In this era the agreement on land pawn was subject to the local customary law where the agreement was carried out.

The term land pawn actually comes from Mr. Van Vollenhoven. This was stated by TerHaar, an agreement 
which led to his land being handed over to receive cash, with a consensus that the surrender would have the right to return the land to himself by paying the same amount of money, so the agreement by Van Vollenhoven was consequently named land pawn or rice field pawn (Terhaar in LiliekIstiqomah, 1982: 52).

The agreement of agricultural land pawn before the publishing of Law No. 56 Prp of 1960 was subject to the customary law of the local community. The implementation of the land pawn is known by the Customary Chief or the Guild Chief, so it must be clear and cash. If this pawn transaction is carried out outside the knowing of the Head of the Guild or Customary Chief, the implementation of the pawn will not be recognized by customary law and therefore the third party is not bound by the legal action, and the rights to the land are not recognized by society members, this is considered as an act that is not bright, meaning that the transaction only involves the parties, namely the owner of the land or also called the pawn seller and the owner of the money or the buyer of the pawn.

In customary law the pawn agreement will run when the pawn seller has received a sum of cash from the pawn buyer and then the landowner hands over the land he owns to the pawn buyer.

After the pawnshop buyer receives the pawned land to him, then he has the right to control the land, in the sense that he can cultivate the land, and so on.

The time for the implementation of pawning in customary law is basically not determined, the pawner is not obliged to redeem the pawn in a certain time. The implementation of the pawning ends when there is a willingness and ability to redeem the pawn, so that the implementation of pawning in customary law cannot be ascertained when it ends (NurRidwan Ari Sasongko, Reportorium Journal, Vol. Nov. 2, 2014: 22). If the pawner dies, then this lien can be inherited to his heirs, so this pawn agreement is sustainable even for up to 100 years, because the pawn recipient may not force the pawn object to be sold to him (RustandiArdiwilaga in Eddy Ruchyat, 1983: 58).

Since the landowners cannot be forced to redeem the pawned land and if the pawn holder at a certain time requires money, then the pawn holder can use his rights: a. divert pawning, namely the pawn holder with the agreement of the landowner to hand over the pawned land to another person, thus the relationship between the pawner and the pawn holder becomes disconnected and changes with the new pawn holder. b. Doubling pawn, that is the situation when pawn holder without approval from the pawner to hand over the pawn land to another person by accepting payments in amounts that may not be the same, in this case the legal relationship between the pawner and the pawn holder was unbroken (LiliekIstiqomah, 1982: 73).

\subsection{Legal Protection on Agricultural Land Pawner after the Issuance of Law No. 56 Prp of 1960.}

Article 10 number 1 UUPA No. 5 of 1960 states, "Every person or legal entity that has a right to agricultural land in principle is obliged to work on or actively cultivate its land by preventing extortion. But in reality and seeing the current condition of the structure of the Indonesian agricultural society, it still requires the use of agricultural land by others. One form of relationship between land use by other parties is a pawn agreement on agricultural land.

What is meant by pawn is the relationship between someone with land owned by someone else, who has a debt of money to him (Article 9 a General Explanation of Law No. 56 Prp of 1960). Furthermore, according to the general explanation Law No. 56 Prp of 1960 article 9 a, as long as the debt has not been paid in full, the land remains in the possession of the pawn holder. As long as the entire land product becomes the right of the pawn holder, which is thus the interest of the debt. Redemption of the land depends on the willingness and ability of the one who pawns it. Many pawns that last for years, decades, even some are continued by pawner heirs and pawning holders, because the pawner is unable to redeem his land again.

Agricultural land pawn is actually classified as temporary land rights as stated in article 53 of UUPA No. 5 of 1960. Therefore, it needs to be removed, but before it can be removed, some regulations must be made that are intended to protect the parties. So to answer this matter the Government published the Law No. 56 Prp of 1960 concerning about "Determination of Agricultural Land Area". One of the important articles discuss about pawn is article 7 of Law No. 56 Prp of 1960. Mentioned by article 7 point 1 that anyone who controls agricultural land with liens which at the time of entry of this regulation has lasted 7 years or more is obliged to return the land to its owner within 1 year after the existing crop has been harvested without there is the right to demand payment of ransom. If the pawn period of agricultural land lasts less than 7 years and if the pawn seller or landowner wants to return to redeem the land that has been pawned, then the liability of the pawn seller to pay ransom is calculated by the formula as follows: $(7+1 / 2)$ multiplied by the pawn money divided by 7 (article 7 number 2 Law No. 56 Prp of 1960).

As mentioned by article 1 of the Minister of Agriculture and Agrarian Regulation No. 20 of 1963 concerning "Guidelines for Settling Pawn Problems", the definition of pawn in article 7 of Law No. 56 Prp of 1960 and its explanation in reality can not only be money, but also objects or services, which can be valued with money.

If customary law is known the deepening discussion of pawn, Regulation of the Minister of Agriculture and Agrarian Affairs No. 20 of 1963 also regulated this matter. It was mentioned in article 2 number 1, if before the period of the pawn ends, the pawn is added either in the form of money or other and the addition is made in writing through the usual way as at the time the pawn was held, then the addition of the new pawn arises, with a new 
amount of money. In this case, the pawn period as intended in Article 7 of Law No. 56 Prp of 1960 it came into force since the pawn was added (article 2 number 2 Regulation of the Minister of Agriculture of Agrarian Affairs No. 20 of 1963).

Regarding what is mentioned by article 7 number 2 above, an example can be stated as follows: pawning amounting to Rp. 140,000, - and the pawn transaction has been going on for 3 years. Then the ransom to be paid by the pawn seller is: 7 1/2 - 3: 7 x Rp. 140,000 - = Rp. 90,000, -

The factor of $1 / 2$ is intended as compensation, if the price does not last up to 7 years (explanation of article 7 of Law No. 56 Prp of 1960).

Furthermore, with the Decision of the Minister of Agriculture and Agrarian Affairs No. SK. 10. ka. 1963 that the provisions of article 7 are affirmed also apply to the agreement of pawn crops, whether which is pawned along with the land or not along with the land.

Article 7 of Law No. 56 Prp of 1960 still requires implementing guidelines, then the Minister of Agriculture and Agrarian Regulation No. 16 of 1964 that the provisions of article 7 are also on pawning about pond.

Looking at article 7 of Law No. 56 Prp of 1960, it can be understood that the substance is to regulate the redemption of pawned land, in other words, limiting the period of time for the pawning agreement and this issue cannot be separated from the time limit for redemption in the pawn agreement as stipulated in customary law. The reality in the society of the implementation of article 7 raises a problem, for example, the law of Minangkabau customary law is to be redeemed without knowing the period of time (Aermadepa, Kostitusi Journal, Vol. 13 No. 3, sept. 2016: 597).

Implementation of land pawn agreement in Bone regency, it was not following what was stipulated in article 7 of Law No. 56 Prp of 1960 that the pawner was still obliged to return the ransom (A. Nuzul: Judicial Journal Vol. 5 No. 2 August 2012: 170).

The agreement on "Gala" (pawn) on agricultural land takes place in the sub-district of MeurahMulia, North Aceh regency also does not follow the rules as it was set out in article 7 paragraph 1 and 2 of Law No. 56 Prp of 1960 specifically that concerns about the duration of the agreement for gala or pawn and the amount of ransom (Marsyuddin: Htps:/media.neliti.com/mediapublication/13952-10-eksadaan-perjanjian-gala. gadai-tanahpertanian-padamasyarakat-aceh-dikecamatan.pdf).

Some cases regarding the implementation of the pawn above show that article 7 of Law No. 56 Prp of 1960 has not yet been realized. Criminal sanctions stipulated in article 10 paragraph 1 of Law No. 56 Prp of 1960 which states that anyone who does not carry out the obligations referred to in Article 3, 6 and Article 7 number 1 , is sentenced to imprisonment for a maximum of 3 months and / or a maximum fine of Rp. 10,000, - also has notbeen realized yet.

If we look closely at the narrative which was built by article 7 of the Law NO. 56 Prp of 1960, in terms of the legal juridical aspect or the landowner is sufficiently protected by his rights. Because it is expressly stated that if the pawning agreement has lasted 7 years or more, the pawn holder must return the land to the owner without the need to pay a ransom. However, if the pawn agreement has not lasted 7 years, then the landowner can ask for the pawned land at any time after the plant on it has been harvested by paying a ransom using the formula: $(7+1 / 2)-$ the pawn period multiplied by the pawn money divided by 7 .

The provisions of Article 7 of Law No. 56 Prp of 1960 was later confirmed again by a Supreme Court decision on March 6, 1971 No.810/e/Sip/1970, which basically states that article 7 of Law No. 56 Prp of 1960 was coercive and could not be softened just because the two parties had made an agreement. In other words, even though the pawner and the recipient of the pawn before carrying out the pawning transaction have agreed to make a rule that deviates from what was mentioned in article 7 of Law No. 56 Prp of 1960, the agreement did not apply because the rule of article 7 of Law No. 56 Prp of 1960 are imperative, cannot be excluded.

\section{Conclusion.}

1. Judging from the juridical aspect of Law No. 56 Prp of 1960 specifically article 7 has provided legal protection to pawners or landowners, then this was reaffirmed by the decision of the Supreme Court on March 6, 1971 No.810/e/Sip/1970.

2. If it is viewed from the side of its implementation, Article 7 of Law No. 56 Prp of 1960 has not been realized yet, the community still applied the pawn system as regulated by customary law where the pawn transaction took place.

\section{References}

[1] Aermadepa, Perlindungan Hak Konstitutional Masyarakat Hukum Adat Minangkabau Dalam Pelaksanaan Gadai Tanah Pertanian” Jurnal Konstitusi, Vol. 13 No. 3, September 2016.

[2] Ari Sasongko, Nur Ridwan, Gadai Tanah/Sawah Menurut Hukum Adat Dari Masa Ke Masa. Jurnal Reportorium, Vol. 1 No. 2, Nov. 2014.

[3] Arikunto, Suharsini, 1996. Prosedur Penelitian Suatu Pendekatan Praktek. Edisi Revisi III. Cet. Kesepuluh. 
Renika Cipta. Jakarta.

[5] Ibrahim, Jhony. 2006. Teori Dan Penelitian Hukum Normatif. Bayu Media Publising. Malang.

[6] Istiqomah, Liliek. 1982. Hak Gadai Atas Tanah Sesudah Berlakunya Hukum Agraria Nasional. Usaha Nasional. Surabaya.

[7] Marzuki, Peter Mahmud. 2007. Penelitian Hukum. Cet. ke - 3. Prenada Media Group. Jakarta.

[8] _. 2014. Penelitian Hukum Edisi Revisi. Cet. Ke-9, Prenada Media Group. Jakarta.

[9] Marsyuddin, Eksistensi Perjanjian Gala (Gadai) Tanah Pertanian Pada Masyarakat Aceh Di Kecamatan Meurah Mulia, Kab. Aceh Utara, Https://media.neliti.com/media/publication-pada-masyarakat-acehdikecamatan.pdf. Di akses 21 September 2017.

[10] Nuzul. A, Penyelesaian Sengketa Tanah Persawahan Dalam Kasus Gadai Yang terindikasi Sandra Putta Kajian Putusan Nomor 34/Pdt.G/2007/PN.WTP. Jurnal Yudisial Vol. 5 No. 2 Agustus 2012.

[11[ Undang-Undang Pokok Agraria No. 5 Tahun 1960.

[12] Undang-Undang No. 56 Prp Tahun 1960 Tentang Penetapan Luas Tanah Pertanian.

[13] Peraturan Menteri Pertanian Dan Agraria No. 20 Tahun 1963 Tentang Pedoman Penyelesaian Masalah Gadai. 